\title{
Estimation of Stature from the Facial and Upper Limb Measurements among the Kattunayakan Tribes of District Madurai, TamilNadu
}

\author{
* Dr. Ajeet Jaiswal, **E.Tamil Selvan \\ * Assistant Professor, Department of Anthropology, Pondicherry University, Puducherry, India \\ ** Research scholar, Department of Anthropology, Pondicherry University
}

\begin{abstract}
Estimation of stature from skeletal remains is one of important factor in forensic identification. In the present study an attempt has been made to formulate estimation of stature using facial and upper limb measurements of Kattunayakans of District Madurai, TamilNadu. A total number of 160(80 Males and 80 Females) Kattunayakans aged from 18 to 48 years. Each subject were measured for the following ten measurements Upper arm length, Radial length, Ulnar length, Hand length, Hand breadth, Palm length, Mid-finger length, Ear length, Nasal height and Facial height besides stature. Here an attempt was to made to determine the relationship between the stature and upper limb measurements.
\end{abstract}

A multiplication factor and linear regression equations was found to be best methods for stature estimation in both males and females among kattunayakans. This study also tries to find out reliable approach to determine the stature.

Keywords: Stature- Estimation; Upper arm length; Forensic anthropology; Kattunayakan.

\section{INTRODUCTION}

Forensic anthropology is the application of the physical anthropologists. It's a specialized knowledge of human, sexual, racial, age and individual variation to problems of medical jurisprudences studies it has emerged as a rigorous sub discipline of physical anthropology that routinely makes key contributions to medico-legal investigation throughout the world. The scope of forensic anthropology is to the identification of human skeleton remains. Although as presently practiced forensic anthropology is largely concerned with skeletal identification only. There are other, non osteological facts of human biological variation fallings within the purview of physical anthropology that are of medico-legal importance for forensic studies. (Krishnan2012) Stature is a descriptive characteristic of an individual, which, after his death in forensic situation, can contribute importantly to his identification (Steele 1970).

Stature estimation is one of several biological parameters that may be usefully compared with antemortem records to include or exclude possible identifications of missing persons. Stature estimation is made possible by the relationship of skeletal dimensions with living height. Skeletal remains will be analyzed in a reliable and systematic manner for the purpose of estimating stature using appropriate techniques and the stature estimation process documented. (jasuja and singh2006) Estimation of stature from skeletal/dismembered remains is not new for forensic anthropologists.

A number of multiplication factors and regression equations have been developed to reconstruct stature from long boner throughout the world. Many studies have been conducted for assessing stature by anthropometric measurements of different parts of the body by anthropologists (jaiswal, 2013; kapoor et al., 2012; Krishnan et al., 2012; Das and Nath, 2012 ; Rastogi et al., 2009; Singh et al., 2006; Nath et al., 2006; Bhavana et al., 2006; Jasuja and Singh, 2004; Sethi and Nath, 2001; Kaur and Nath, 1997; Rautry, 1995; Anand, 1990; Kapoor, 1987; Tiwary, 1986; Bhatnagar et al., 1984)

The present study dealt with a regression equation for stature estimation to find out the correlation with stature by using upper ad facial measurements of kattunayakan tribes. 


\section{MATerial AND MeTHOD}

The present study was carried out in Samayanallur village of District Madurai in TamilNadu. A total number of 160 people formed the sample size of the study which included a total of 80 males and 80 females. Subjects from 50 households were studied. From each household, representative numbers of subjects were interviewed. Male and female measured without any deformity for all eleven measurements.

\subsection{Kattunayakan Tribe}

Kattunayakan is one of the scheduled tribe lives in Madurai district, TamilNadu. The Kattunayagan people live in Samayanallur village of Madurai district claims their identity as kattunayakan tribes.

At local level, the same community is referred to by different names like kudukudupukaran, kambalatha naicker, josyakarar etc. In Samayanallur at present totally in one settlement 50 houses are occupied by this community. The community people also living some other districts like VirudhuNagar, Coimbatore, Tiruchirapalli, Theni, Dindigul and some other parts of TamilNadu. The community identification marks are male and female tattooing, female brass ornaments, male head gear and coloured clothes which reveals nomadic profession. They are non-vegetarians eat plenty of trapped small animals and birds. They staple food is rice and groundnut oil for cooking. The duration of my fieldwork is only one phase. My field work started on January $1^{\text {st }}$ January 2012 to 10th February 2012. During these 41 days, first 15 days I collected data on ethnographic profile or area and people and other reports on their daily activities of the subject. After, I was able to do and collect detail information regarding the Estimation of stature from the facial and upper limb measurement among the Kattunayakan tribes of the respected village.

\subsection{Selection of Body Measurements}

The selection and techniques of body measurements depend upon the purpose of the study, to suit the problem under study. Thus following measurements have been obtained on each subject using the standard techniques recommended By Martin and Saller (1959), Allbrook (1961). All the measurements listed have been taken on the left side of the body. Most of the studies conducted by researchers till date primarily pertain to the long bone lengths while some studies have incorporated certain other body measurements as well the total measurements incorporated in the present study are as follows.

\section{$>$ Stature(S)}

It is obtained as the projective distance between the standing surface and the highest point on the (vertex), when the subject is standing in the standard standing position using anthrop meter rod.

\section{$>$ Upper arm length (UAL)}

It is obtained as a direct distance between the left acromion and the lower end of medial epicondyle of humorous, using rod compass.

\section{$>$ Radial length $(\mathrm{RL})$}

The left forearm was flexed and semiporonated with hand in natural position, using the rod compass, the distance between the tips of styloid process palpable at wrist thumb joint was measured.

\section{$>$ Ulnar Length (UL)}

The left forearm was flexed and semiporonated with hand in natural position using the rod compass, the distance from the tip to the olecranon process to the distal margin of ulnar head palpable on the dorsum of the wrist little finger joint was measured.

\section{$>$ Hand Length (HL)}

It is obtained as a distance between the proximal bracelet crease and dactylion using sliding calliper while taking the measurement, left hand of the subject was placed on a horizontal surface with the palm facing upwards.

\section{$>$ Hand Breadth $(\mathrm{HB})$}

It is obtained as a distance between the metacarpal radiale and metacarpal ulnare while taking the measurement, left hand of the subject was on a horizontal surface with the palm facing downward. 
Estimation of Stature from the Facial and Upper Limb Measurements among the Kattunayakan Tribes of District Madurai, TamilNadu

\section{Palm Length (PL)}

It is obtained between the proximal wrist crease and the proximal Metacaropphalageal crease at base of the middle finger with the palm facing upwards.

\section{Mid-Finger Length (MFL)}

It measures the distance between metacarpal third and the top of the Middle finger, when the left hand is placed on a horizontal surface with the palm facing downwards using sliding calliper.

\section{$>$ Ear Length (EL)}

It measures the straight distance between the superaurale (sa) and subaurale (sba) in eye ear plane. For an accurate finding measurement should be taken at right angles to mid-sagittal plane using sliding calliper.

\section{$>$ Nasal Height $(\mathrm{NH})$}

It measures the straight distance between the nasion(n) and subnasion(sn), using sliding calliper.

\section{$>$ Facial Height $(\mathbf{F H})$}

It measures the straight between the nasion(n) and prosthion(pr), using sliding Calliper

Data has been subjected to statistical analysis for assessing sex differences in different measures of the upper arm length, facial measurement and stature to formulate multiplication factors and regression equation for estimation of stature from all the ten measurements.

\section{RESULTS AND DISCUSSION}

Table1. Measures of Mean, Standard Deviation and Standard Error of Mean for Different Body Measurements among Females

\begin{tabular}{|l|l|l|l|l|}
\hline S. No & Body Measurements & Mean & Standard Deviation(S.D.) & Standard Error of Mean(S.E.) \\
\hline 1. & Stature & 151.04 & 6.25 & 0.70 \\
\hline 2. & Upper arm length & 28.66 & 2.34 & 0.26 \\
\hline 3. & Radial length & 21.24 & 1.75 & 0.20 \\
\hline 4. & Ulnar length & 22.52 & 2.14 & 0.24 \\
\hline 5. & Hand length & 15.24 & 1.36 & 0.15 \\
\hline 6. & Hand breadth & 9.88 & 1.27 & 0.14 \\
\hline 7. & Palm length & 9.44 & 2.24 & 0.25 \\
\hline 8. & Mid-finger length & 7.07 & 0.69 & 0.07 \\
\hline 9. & Ear length & 5.68 & 0.49 & 0.05 \\
\hline 10. & Nasal height & 4.48 & 0.98 & 0.11 \\
\hline 11. & Facial height & 5.54 & 0.56 & 0.06 \\
\hline
\end{tabular}

Table 1 shows the maximum mean values (151.04) and minimum mean values (4.48), maximum standard deviation (S.D) is (6.25) and minimum standard deviation (0.49) and maximum standard error of mean (0.70) and minimum standard error of mean (0.05). It describes all the ten measurements pertaining to upper extremity and facial measurements besides stature of Kattunayagan females of Madurai district, TamilNadu.

Table2. Measures of Mean, Standard Deviation and Standard Error of Mean for Different Body Measurements among Males

\begin{tabular}{|c|l|l|c|c|}
\hline S. No & Body Measurements & Mean & Standard Deviation(S.D.) & Standard Error of Mean(S.E.) \\
\hline 1. & Stature & 165.66 & 5.38 & 0.60 \\
\hline 2. & Upper arm length & 31.16 & 2.08 & 0.23 \\
\hline 3. & Radial length & 24.54 & 1.99 & 0.21 \\
\hline 4. & Ulnar length & 25.74 & 1.93 & 0.22 \\
\hline 5. & Hand length & 16.96 & 1.09 & 0.12 \\
\hline 6. & Hand breadth & 11.07 & 0.84 & 0.09 \\
\hline 7. & Palm length & 9.67 & 0.60 & 0.07 \\
\hline 8. & Mid - finger length & 7.78 & 0.56 & 0.06 \\
\hline 9. & Ear length & 5.87 & 0.44 & 0.05 \\
\hline 10. & Nasal height & 4.68 & 0.40 & 0.04 \\
\hline 11. & Facial height & 5.72 & 0.50 & 0.06 \\
\hline
\end{tabular}




\section{Dr. Ajeet Jaiswal \& E.Tamil Selvan}

Table 2 shows the maximum mean values (165.66) and minimum mean values (4.68), maximum standard deviation (S.D) is (5.38) and minimum standard deviation (0.40) and maximum standard error of mean (0.60) and minimum standard error of mean (0.04). It describes all the ten measurements pertaining to upper extremity and facial measurements besides stature of Kattunayagan males of Madurai district, TamilNadu.

It is observed that the Kattunayagan males are not only taller than females but they also greater values for certain measurements pertaining to upper extremity, and facial measurements. The sex difference between the statures is greatest in comparison to the rest of the measurements.

Table3. Sex Differences in Different Body Measurement of Kattunayakans in Madurai, Tamil Nadu

\begin{tabular}{|c|l|l|}
\hline S. No. & Body Measurements & t-Value \\
\hline 1. & Stature & $15.78^{*}$ \\
\hline 2. & Upper arm length & $7.07^{*}$ \\
\hline 3. & Radial length & $10.92^{*}$ \\
\hline 4. & Ulnar length & $9.98^{*}$ \\
\hline 5. & Hand length & $8.75^{*}$ \\
\hline 6. & Hand breadth & $6.91^{*}$ \\
\hline 7. & Palm length & $0.72^{*}$ \\
\hline 8. & Mid-finger length & $7.06^{*}$ \\
\hline 9. & Ear length & $2.60^{*}$ \\
\hline 10. & Nasal length & $1.75^{*}$ \\
\hline 11. & Facial height & $2.19^{*}$ \\
\hline
\end{tabular}

* significant at 0.01 level

On subjecting the data to test of significance (t-test) to evaluate the sex difference. It is revealed that all body measurements exhibit significant sex differences.

Owing to the significant $(\mathrm{p}<0.01)$ sex differences, the sexes have been dealt with separately for further analysis related to computation of multiplication factor and linear regression equation for estimation of stature from different body measurements.

Formulation of Sex Specific Multiplication Factor (M.F) for Estimation of Stature Among Kattunayakan Male and Females of Madurai:

Table 4 and Table 5: Display the multiplication factor values for all the ten measurements pertaining to upper extremity and facial measurements besides stature among Kattuanayakan Males and Females.

Table4. Multiplication Factor of Different Body Measurement for Estimation of Stature among Kattunayakan Females of Madurai

\begin{tabular}{|c|l|l|}
\hline S. No & Body Measurements & Females \\
\hline 1. & Upper arm length & 5.30 \\
\hline 2. & Radial length & 7.13 \\
\hline 3. & Ulnar length & 6.75 \\
\hline 4. & Hand length & 9.99 \\
\hline 5. & Hand breadth & 15.43 \\
\hline 6. & Palm length & 16.51 \\
\hline 7. & Mid-finger length & 21.49 \\
\hline 8. & Ear length & 26.80 \\
\hline 9. & Nasal height & 34.48 \\
\hline 10. & Facial height & 27.55 \\
\hline
\end{tabular}

Table5. Multiplication Factor of Different Body Measurement for Estimation of Stature among Kattunayakan Males of Madurai

\begin{tabular}{|c|c|c|}
\hline S. No & Body Measurements & Males \\
\hline 1. & Upper arm length & 5.33 \\
\hline 2. & Radial length & 6.78 \\
\hline 3. & Ulnar length & 6.46 \\
\hline 4. & Hand length & 9.80 \\
\hline 5. & Hand breadth & 15.04 \\
\hline
\end{tabular}


Estimation of Stature from the Facial and Upper Limb Measurements among the Kattunayakan Tribes of District Madurai, TamilNadu

\begin{tabular}{|c|c|c|}
\hline \hline 6. & Palm length & 17.17 \\
\hline 7. & Mid-finger length & 21.38 \\
\hline 8. & Ear length & 28.36 \\
\hline 9. & Nasal height & 35.57 \\
\hline 10. & Facial height & 29.14 \\
\hline
\end{tabular}

Using the proportion of ten percutaneous length of stature, multiplication factors have been computed for Kattunayagan Males and Females of Madurai.

It is observed from the table 4 and 5 that females shows higher values of multiplication factor for Radial length(5.13), Ulnar length(6.75), Hand length(9.99), Hand breadth(15.43) and Mid-finger length(21.49) while for the rest of the measurement Palm Length(17.17), Ear Length(28.36), Nasal Length(35.57), Facial Length(29.14) Male exhibit higher values of multiplication factor.

It is observed from the table 4 and 5 nasal height exhibits the highest value of multiplication factor and upper arm length exhibit the lowest value for both males and females. As different values of multiplication factors are observed for male and female thus they exhibit the different variation in their physique.

\section{Computation of Correlation between Stature and Different Body Measurements among Kattunayagan Males and Females:}

With a view to observe the association between individual body measurements and stature, the data have been subjected to correlation analysis. The type of relationship a body measurement with stature is an immense importance to identify as to which body measurement is likely to provide an estimate of stature closest to the actual stature among kattunayagan males and females.

Table6. Correlation Value of Different Body Measurement with Stature among Kattunayakan Females

\begin{tabular}{|c|c|c|}
\hline S. No & Body Measurements & Correlation Values(r) \\
\hline 1. & Ulnar length & 0.25 \\
\hline 2. & Mid-finger length & 0.56 \\
\hline 3. & Upper arm length & 0.46 \\
\hline 4. & Radial length & 0.41 \\
\hline 5. & Palm breadth & 0.49 \\
\hline 6. & Hand breadth & 0.44 \\
\hline 7. & Hand length & 0.46 \\
\hline 8. & Nasal height & 0.06 \\
\hline 9. & Facial height & 0.05 \\
\hline 10. & Ear length & \\
\hline
\end{tabular}

Table 6 presents the correlation values of different body measurements with stature among Kattunayagan Females of Madurai. The overall highest correlation is exhibited by mid-finger length $(r=0.56)$ followed by palm length $(r=0.49)$ and the least correlation values is observed by ear length $(\mathrm{r}=0.05)$ with stature.

Table7. Correlation Value of Different Body Measurement with Stature among Kattunayakan Males

\begin{tabular}{|l|l|l|}
\hline S. No & Body Measurements & Correlation Values(r) \\
\hline 1. & Upper arm length & 0.46 \\
\hline 2. & Radial length & 0.42 \\
\hline 3. & Ulnar length & 0.44 \\
\hline 4. & Mid-finger length & 0.57 \\
\hline 5. & Hand length & 0.45 \\
\hline 6. & Palm breadth & 0.44 \\
\hline 7. & Hand breadth & 0.32 \\
\hline 8. & Facial height & 0.16 \\
\hline 9. & Ear length & 0.18 \\
\hline 10. & Nasal height & 0.17 \\
\hline
\end{tabular}

Table7 presents the correlation values of different body measurements with stature among Kattuayakans the overall highest correlation is exhibited by mid-finger length( $\mathrm{r}=0.57)$ followed by upper arm length( $r=0.46)$ and the least correlation is exhibited by facial height $(r=16)$ with stature. 


\section{Dr. Ajeet Jaiswal \& E.Tamil Selvan}

On comparing the pattern of relationship between stature and different body measurements among both kattuayagan males and females. It is observed that the two sex show sufficient variation.

\section{Construction of Linear Regression Equations for Stature Estimation among Kattunayakan Males and Females of Madurai:}

Out of two mathematical methods of stature, i.e.by regression equations and multiplication factors, the regression formulae provide greater accuracy in predicting stature in comparison to the multiplication factors, because they are based on the degree of association that a body measurement exhibits with stature.

Table8. Linear Regression Equation for Estimation of Stature among Kattunayakan Females of Madurai

\begin{tabular}{|c|l|l|c|c|}
\hline S.No. & Body Measurements & Equation & $\begin{array}{l}\text { Standard Error of } \\
\text { estimate(SEE) }\end{array}$ & $\begin{array}{l}\text { Correlation } \\
\text { value }\end{array}$ \\
\hline 1. & Upper arm length & $116.67+1.20(\mathrm{UAL})$ & \pm 5.59 & 0.46 \\
\hline 3. & Radial length & $119.27+1.49(\mathrm{RL})$ & \pm 5.72 & 0.42 \\
\hline 4. & Ulnar length & $134.67+0.73(\mathrm{UL})$ & \pm 6.09 & 0.25 \\
\hline 5. & Hand length & $119.39+2.08(\mathrm{HL})$ & \pm 5.60 & 0.46 \\
\hline 6. & Hand breadth & $129.68+2.17(\mathrm{HB})$ & \pm 5.64 & 0.44 \\
\hline 7. & Palm length & $149.81+0.14(\mathrm{PL})$ & \pm 6.28 & 0.05 \\
\hline 8. & Mid - finger length & $114.72+5.14(\mathrm{MFL})$ & \pm 5.19 & 0.57 \\
\hline 9. & Ear length & $147.51+0.63(\mathrm{EL})$ & \pm 6.28 & 0.05 \\
\hline 10. & Nasal height & $148.20+0.65(\mathrm{NH})$ & \pm 6.26 & 0.10 \\
\hline 11. & Facial height & $147.61+0.63(\mathrm{FH})$ & \pm 6.28 & 0.06 \\
\hline
\end{tabular}

Table 8 expresses the linear regression formulated for estimation of stature from different body measurements for the Kattunayagan females of Madurai. These linear regression equations have been formulated on the basis of correlation values. The overall highest correlation is exhibited by mid-finger length $(r=0.57)$ followed by upper arm length $(r=0.46)$, hand length $(r=0.46)$ and the least correlation is exhibited by ear length (0.05), palm length (0.05). Among different body measurements of upper extremity, mid-finger length $(\mathrm{r}=0.57)$ shows the highest correlation with stature while the least correlation is observed by ulnar length $(\mathrm{r}=0.25)$.

Table9. Linear Regression Equation for Estimation of Stature among Kattunayakan Males of Madurai

\begin{tabular}{|l|l|l|l|l|}
\hline S. No. & $\begin{array}{l}\text { Body } \\
\text { Measurements }\end{array}$ & Equation & $\begin{array}{l}\text { Standard Error } \\
\text { of estimate(SEE) }\end{array}$ & $\begin{array}{l}\text { Correlation } \\
\text { value }\end{array}$ \\
\hline 1. & Upper arm length & $128.65+1.19(\mathrm{UAL})$ & \pm 4.81 & 0.46 \\
\hline 3. & Radial length & $137.74+1.14(\mathrm{RL})$ & \pm 4.91 & 0.42 \\
\hline 4. & Ulnar length & $134.26+1.12(\mathrm{UL})$ & \pm 4.87 & 0.44 \\
\hline 5. & Hand length & $127.79+2.23(\mathrm{HL})$ & \pm 4.83 & 0.45 \\
\hline 6. & Hand breadth & $142.97+2.05(\mathrm{HB})$ & \pm 5.13 & 0.32 \\
\hline 7. & Palm length & $127.66+3.93(\mathrm{PL})$ & \pm 4.86 & 0.44 \\
\hline 8. & Mid - finger length & $123.15+5.46(\mathrm{MFL})$ & \pm 4.45 & 0.57 \\
\hline 9. & Ear length & $153.12+2.13(\mathrm{EL})$ & \pm 5.33 & 0.18 \\
\hline 10. & Nasal height & $154.46+2.39(\mathrm{NH})$ & \pm 5.33 & 0.17 \\
\hline 11. & Facial height & $155.87+1.71(\mathrm{FH})$ & \pm 5.35 & 0.16 \\
\hline
\end{tabular}

Table 9 expresses the linear equation for estimation of stature from all the ten body measurements for the Kattunayagan males of Madurai. These linear regression equations have been formulated on the correlation basis. The overall highest correlation values is exhibited by mid- finger length $(r=0.57)$ followed by upper arm length $(\mathrm{r}=0.46)$ and the least correlation values is exhibited by facial height $(\mathrm{r}=0.16)$. Among different body measurements of upper extremity, mid- finger length $(\mathrm{r}=0.57)$ shows the highest correlation with stature while the least correlation is observed by hand breadth $(\mathrm{r}=$ 0.32 ).

It is observed that linear regression equations formulated on the basis of correlation values for estimation of stature shows sex variability among Kattunayagans in terms of body relationship of different body measurements.

Data was analysed using SPSS statistical package for analysis of Standard error of means, standard deviation, t-test, and correlation and regression analysis was used for formulating linear regression equation for the estimation of stature. 
Analysis of the data reveals that the Kattunayakan males exhibit greater mean values than the Kattunayakan females for all the measurements including stature. The data were subjected to test of significance (t-test) to assess sex difference and on subjecting data to test of significance to evaluate the sex difference it is revealed that all the body measurements exhibit significant differences.

Owing to the significant $(\mathrm{p}<0.01)$ sex differences, the sexes have been dealt with separately for further analysis related to computation of multiplication factors and linear regression equation for estimation of stature from different body measurements.

The multiplication factors for all the ten body measurement reveals that female show higher values of multiplication factor for radial length, ulnar length, hand length, hand breadth and mid- finger length while for the rest of the measurements i.e. For upper arm length, nasal length, ear length and facial height values male exhibit the higher values of multiplication factor.

As different values of multiplication factor are observed for male and female Kattunayakans, thus they exhibit variation in their physique. Pearson correlation coefficient $(r)$ has been obtained between stature and different body measurements to assess relationship between various limb bone and facial measurements with stature among both the sexes.

Among male Kattunayakan of Madurai the overall highest correlation is exhibited by mid- finger length $(\mathrm{r}=0.57)$ followed by upper arm length $(\mathrm{r}=0.46)$ and least correlation values is observed by facial height $(\mathrm{r}=0.16)$ with stature. While among female Kattunayagan the overall highest correlation is exhibited by mid-finger length $(\mathrm{r}=0.57)$ followed by upper arm length $(\mathrm{r}=$ $0.46)$, hand length $(r=0.46)$ and the least correlation is observed by ear length $(r=0.05)$ with stature.

On comparing both the sexes of Kattunayakan of Madurai, the pattern of relationship with stature show sufficient variation for all the ten measurements. Based on the extent of relationship between different body measurements and stature, regression equations have been formulated for either population to estimate stature. A body measurement that correlates highly with stature would provide more accurate estimate of stature as compared to the ones with relatively low correlation with stature

Linear regression equations are formulated on the basis of correlation value for estimation of stature show variability among male and female Kattunayakans in terms of relationship of different body measurements with stature. In males, best estimate of stature would be obtained mid-finger length and secondly by upper arm length but females' best estimate of stature would be obtained by midfinger length and then palm length.

\section{LIMITATION OF THE STUDY}

The Present study is mainly confined to the Madurai District of TamilNadu, no other part of India. The present study the sample size taken into consideration was small as compared to the existing population of the place. Data is not available with regard to the drought, because some of the persons went outside for job.

\section{Conclusion}

The present study is an attempt to evaluate a possible correlation between stature of an individual \& ten measurements; individually in tribes of Kattunayakan. It was found that all the ten measurements showed a correlation with stature but at different degrees (significance calculated through the paired t-test). Among male Kattunayakan of Madurai the overall highest correlation is exhibited by mid-finger length $(r=0.57)$ followed by upper arm length $(r=0.46)$ and least correlation values is observed by facial height $(\mathrm{r}=0.16)$ with stature. While among female Kattunayakan the overall highest correlation is exhibited by mid-finger length $(\mathrm{r}=0.57)$ followed by upper $\operatorname{arm}$ length $(\mathrm{r}=$ $0.46)$, hand length $(\mathrm{r}=0.46)$ and the least correlation is observed by ear length $(\mathrm{r}=0.05)$ with stature.

Mathematical formulae for estimating stature were developed for each of these measurements through basic linear regression. It can be concluded that the present study has provided regression equations for ten different parameters that can be used for stature estimation of Kattunayakans.

In this present study both male and female subjects used also yielded correlation coefficient and coefficient of determination. Linear regression equation was drawn which were helpful for estimation 
of stature from respective upper arm length and facial measurements for both male and females. The regression equations further confirmed the reliability of the findings of this study.

\section{ACKNOWLEDGEMENT}

We are extremely thankful to all the people of Kattunayakan Tribes of District Madurai, TamilNadu for their cooperation and continuous support which made this work possible. My sincere thanks to all the other member of the Department and tribal friends for the valuable motivation and help.

\section{REFERENCES}

[1] Allbrook, D. 1961. The estimation of stature in British and East African males based on tibial and ulnar bone length. J.For.med. 8:15-28.

[2] Anand, N. (1990) Use of percutaneous of body in reconstruction of stature: A forensic anthropological study of Brahmins and Rajputs of Garhwal(Uttar Pradesh).Unpublished, M.Sc. dissertation, , University of Delhi, Delhi

[3] Bhatnagar D.P, Thapar S.P and Batish M.K1984, Identification of personal height from somatometery of hands in the Punjabi males, Forensic science international, 24: 137-147.

[4] Bhavana and Nath, S 2006. Restoration of stature using hand and foot lengths among Shia Muslims of Delhi. In modern trends in forensic science. (Eds) Ramesh Chandra, Surinder Nath and Parveen Janjua. Shree publishers and distributors, Delhi; 146-152.

[5] Das,A.P and Nath, S. 2012. Stature estimation through lower limb measurements among Kshatriya females of Orissa. Voice of intellectual man, Vol.2, No.2, july-dec., 2012, 139-150.

[6] Jaiswal, A. 2013. Estimation of Stature from Lower Extremity among the Santhal Tribe of Odisha, India. Indian J. Forensic Medicine and Toxicology, vol. 7,1.jan-june.254-287.

[7] Jasuja O. P. and Singh G. 2004. Estimation of Stature from hand and Phalange length. JIAFM, vol.26(3):0971-0973.

[8] Jaiswal, A.2011. Prediction of Stature from hand lengths among Indians. . Indian J. Forensic Medicine and Toxicology.

[9] Krishan K, Kachan T, Sharma A 2012. Multiplication factor versus regression analysis in stature estimation from hand and foot dimensions. Journal of Forensic and Legal Medicine. ; 19(4):211-14.

[10] Kapoor. A.K., Duggal. N and Nath. S. 1986. Reconstruction of Stature Through Percutaneous

[11] Length of Ulna and Tibia Among Lodhas of Dist. Midnapore, West Bengal. Man and Life, 12:41- 46.

[12] Kaur, S. and Nath, S 1997. Reconstruction of stature from various dimensions of upper extremity among Sikh females of Delhi. Proceedings of $\mathrm{X}$ All India Forensic science Conference, Bhubaneswar (11-13 Nov., 1997) 6-16.

[13] Martin ,R, Saller.1957K Lehrbuch der Anthropologie, Stuttgart.

[14] Nath.S. 1993. Anthropometry- The measurement of Body Size, Shape and Form. Friend's Publication, Delhi.

[15] Nath .S., 1996. Forensic Anthropology .Ashtam Prakasthan, Delhi

[16] Rastogi Kanchan, Menezes, T. and Yoganarasimha,. K. 2009. Mid-finger length a prediction of stature in the Indian population. Med. Sci. Law., 49(2): 123-126.

[17] Rautray, N. 1995. Estimation of Stature Through Percutaneous Measurements of Upper and Lower Extremities Among Male and Female Jats of Churu, Rajasthan. Unpublished, M.Sc. dissertation, Uiversity of Delhi, Delhi.

[18] Sethi, V. 1998. Determination of stature on the basis of percutaneous measures of the upper and lower extremities among Punjabi and Jain females of Delhi. Unpublished M.Phil. Dissertation, Univ. Delhi.

[19] Singh, S. Nath, S. and Singla, S. 2006. Reconstruction of stature through upper limb measurements among Brahmins of Jhansi, Bundelkhand. In modern trends in forensic science. (Eds) Ramesh Chandra, Surinder Nath and Parveen Janjua. Shree publishers and distributors, Delhi 81-88. 
Estimation of Stature from the Facial and Upper Limb Measurements among the Kattunayakan Tribes of District Madurai, TamilNadu

[20] Stewart T. D.1979. Essential of Forensic Anthropology. Springfield, Il: Charles C. Thomas; 255-74.

[21] Tiwary, M. 1986. Reconstruction of stature on the basis of certain body measurements among Brahmin and Rajputs of Ranikhet, U.P., Unpublished Master's. Dissertation, Univ. Delhi.

[22] Vijeta, P. Bhasin and A.K. Kapoor. 2012. Forensic Anthropology and Genetics: Futuristic Dynamics.

[23] Vijeta, P., and Kapoor, A.K., 2012. Estimation of Stature from Hand Length and Hand Breadth among Population Groups of Himachal Pradesh. Asian J. Science \& Applied Technology (Accepted)

[24] Weiner, J.S. Lourie, J.A. 1981Human Biology: A Guide to Field Methods. -International Biological Programme, IBP No. 9.Marylebone London. NW 